(C) 2018

\title{
Spread of staphylococcus and diseases caused by them
}

\author{
Vishovan Yu, Ushkalov V. \\ National University of Bioresources and Life Sciences of Ukraine.
}

The purpose. To analyze results on epizootic/epidemic supervision of staphylococcal infection contaminations in Ukraine and the world. Methods. Retrospective analysis of accessible references concerning spread of staphylococcus and diseases caused by them is carried out. Informational resources of international organizations (WHO; FAO; UN, European center for supervision and warning of diseases $(E C D C)$, European department on safety of foodstuff (EFSA), special literature, etc.) allocated on Internet sources are studied. Results. Global problem is illuminated of circulation of staphylococcus among animals and people, contamination by them of plants of environment, in particular water, food stuffs of animal and vegetable origin, etc. Necessity is shown of detection of Methicillinum-resistant clones of staphylococcus among productive animals, animals-partners and people, and also urgency of reinforced monitoring over contamination of animal production, etc. Conclusions. Necessity is determined of implementation of the system of target monitoring over staphylococcus, in particular Methicillinum-resistant, as a link in circuit of measures aimed at prophylaxis of diseases, caused by microorganisms of that family.

Key words: staphylococcus, resistance, carrying agent, antibiotics, Penicillinum-fixing protein.

Introduction. In accordance with the WHO, OIE strategy "only care» ( «One Health»), attention that ensure the protection of public health, and should focus on the study of the biological characteristics of potential pathogens - pathogens zooantroponoziv in order to implement effective measures to prevent diseases. Stafilokokoz - infectious disease of all kinds of domestic and some wild animals and humans that affects the respiratory system, skin, genitals, breast, (possible septicemia); a bird with acute or chronic course - appears as arthritis, synovitis, dermatitis, sinusitis and inflammation kloatsytu earrings. The main place of localization of staphylococci in the host's organism is the skin, mucous membranes and intestines. Staphylococci are part of the normal flora of the body of animals and humans are in symbiosis with it, however, compromised immune status of the body, causing diseases of other organs and tissues. In the environment of staphylococci come from sick animals and humans and clinically healthy carriers of these microorganisms. They are constantly in the air, water, soil, on various items of use. When in contact with sick individuals may be formed resident staph bacteria when permanent place of residence is nasal mucosa, where they spread the secrets. Such carriers are particularly dangerous among the medical staff of hospitals, as carriers can be a source of internal hospital infections [1]. Often, the factors contributing to the disease are contaminated crop products, livestock (milk, meat) and fish. Common cases of infection through soil, water, from sick and asymptomatic carriers of the causative agent (animals and humans), and during various medical manipulations. That is, the disease of animals and humans, caused by representatives of the genus Staphylococcus, can be attributed to a group of endangered diseases.

The problem of staphylococcal infection, despite the significant issues Epizootology study and diagnosis of the causative agent, has attracted the attention of researchers due to the relatively high registration diseases (especially among humans) caused by staphylococcus, identify new pathogenicity factors (formation of bacterial biofilms, etc.) . The prevalence of staphylococci in nature, reports of a tendency towards increased resistance of staphylococci to antibacterial agents, cases of intractable outbreaks of staphylococcal infections, long asymptomatic staphylococoniosis in humans and animals with possible cross-contamination, significant economic losses from morbidity, decreased productivity, death of farm animals, as well as significant Expenses for preventive measures and hospitalization of patients with staphylococcus aureus (treatment, bactericide rejuvenation, etc.) sta The basis for conducting these studies. 
The purpose of the work is to analyze the results of the epidemiological / epizootic surveillance of staphylococcal infections in Ukraine and in the world.

Materials and methods. For the analysis of the epidemic and epizootic situation, a retrospective analysis of available literature sources on the prevalence of staphylococci and the diseases caused by them was carried out. To study the issue in the global information space, the information resources of the Internet of international organizations (WHO, FAO, UN, data from the European Center for Disease Control and Prevention (ECDC), European Food Safety Authority (EFSA), special literature, etc.) have been processed.

Results and discussion. According to the "Determinant of bacteria of Berge", the genus Staphylococcus has more than 20 species, most of which are saprophytes. Staphylococci are grampositive bacteria of spherical shape, which occur in the form of clusters resembling grapes. In 1884, Rosenbach described two types of pigmented colonies of staphylococci and suggested the appropriate nomenclature: Staphylococcus aureus, gold staphylococcus (yellow) and Staphylococcus albus (white). The latter species is now called Staphylococcus epidermidis. Taxonically, the genus Staphylococcus belongs to the Staphylococcaceae family, which includes three lesser genera, namely Gamella, Macrococcus and Salinicoccus [2]. Most important are the types of S. aureus, S. epidermidis, S. saprophyticus - which are pathogenic for humans and animals $S$. Intermedius - pathogenic for animals and [3] in some cases participate in the occurrence of different forms of the disease in humans S. Hyicus, S. capitis, S. haemolyticus, S. hominis, S. warneri, S. cohnii.

$S$. aureus (among other members of the family) is the most pathogenic and potential etiological factor may be a number of diseases in humans and animals, its pathogenicity is mainly related to the toxin, invasiveness and resistance to antibiotics. The European agency for food safety (European Food Safety Authority) emphasized the need to track methicillin-resistant (MRSA) clones staphylococci in animal products (detection and quantification of MRSA in populations of people, animals, food, environmental objects) [4]

Staphylococci - bacteria of a spherical shape, their sizes are 0.8-1.1 microns in diameter, are placed in the form of improper clumps resembling bunch of grapes, in smears from pathological material are arranged in pairs. These are stationary bacteria, capsules and spores do not form, gram-positive. In old cultures, some cells are stained with Gram negative. Staphylococci constitute about 10 types of exotoxins [4]. Source of the pathogen. Sick animals, animals-bacteriocarriers. Ways of infection are alimentary, contact through damaged skin, possible vertical transmission of the pathogen. Factors for the transmission of infected food, feed (meat, milk, other products of animal origin), water, excrement and excrement of diseased animals.

For the development of the disease in many cases requires certain conditions - contributing factors: imunodyfitsytnyy state ecological balance between fellow-members microbiota animals subclinical or clinical forms of metabolic disorders, diagnostic and cosmetic manipulations, leading to disruption of the integrity of skin and mucous membranes, and so on. The development of disease is caused by the pathogen penetration through damaged skin or mucous membranes, followed by Staphylococcus blood fall in domestic parenchymal organs, proliferate, and the environment in significant quantities allocated exotoxins, which are the body and causes the major symptoms of the disease. In some cases, staphylococci cause secondary illness with whiskey, influenza, wound infections, and postoperative sepsis [5].

Particularly acute is the problem of mastitis in cattle where staphylococci play a leading role. Common cases of disease among dogs in the form of pyoderma, otitis, vaginitis and mastitis in females, postulated in males. Highly susceptible to rabbit staphylococci, especially young, in which apart from pyoderma and pododermatitis, septicopimeemia may develop. In poultry, staphylococci cause acute and chronic forms: acute forms of dermatitis appear and chronic conditions affect the tendon vagina and joints, which leads to the ankylosis of the latter. Newborn young animals are found in omphalis. In pigs, staphylococcal lesions are rarely seen in isolated cases in young animals in the form of arthritis, amphalitis, and in older animals, 
abscesses are found mainly during slaughter. Pedan V.A. (2005) for the first time in Ukraine described in detail the manifestations of staphylococcus aureus, acute and chronic form of the disease [6].

Staphylococci are pathogens of human pyoderma. When studying antibiotic susceptibility to bacteria that were isolated from pathological cells on the skin, it was found that the vast majority of strains were resistant to a number of antibacterial drugs. Staphylococci in $20-80 \%$ of cases were resistant to benzylpenicillin, ampicillin, carbenicillin, methicillin, streptomycin, oleandomycin, neomycin, tetracycline, chloramphenicol. From 80 to $100 \%$ of staphylococci were susceptible to oxacillin sodium, lincomycin hydrochloride, gentamicin sulfate, erythromycin, less susceptible to oleandomycin, streptomycin sulfate, neomycin, less susceptible to benzylpenicillin, carbenicillin, disodium salt. Coagulase-positive staphylococci were more susceptible to antibiotics than coagulase-negative species $[7,8]$. Also important is the frequency of nasal carriage of $\mathrm{S}$. aureus in the medical staff of the surgical departments and medical students. Available dependence on the season is the frequency of carrier of staphylococcus aureus in a student.

The published report [10] on the results of screening staphylococci 14 (203 sample) dairy farms in Algeria: staphylococcus was found in 30 percent of cows, of which $67.21 \%$ - koahulazonehatyvni and $32.79 \%$ - koahulazopozytyvni staphylococci. ES Donkor et al. [11] reported that in the study of raw milk in two cities of the Ghana Republic of Accra and Kumasi, besides Yersin, Klebsiel, Protea, and Escherichia coli, staphylococci were found in approximately $14.6 \%$ of samples. In the study of raw milk on farms in Nigeria Udi isolates revealed 16 different microorganisms (Bacillus, Escherichia coli, Klebsiella, Streptococcus, Rhizopuss, Fusarium) are kind of staph -3, representing 18.75\% [12]. Sileshi Shiferaw and Munees Ahmad report data on the isolation of staphylococcus aureus from 98 samples $(45 \%)$ of raw milk from Ethiopian cows, $96 \%$ of the isolates were resistant to one or more antibiotics [13]. In the region of Tigray (Ethiopia), in milk and dairy products, staphylococci were found to be $47 \%$ and $28.8 \%$ respectively: $51.6 \%$ of them were coagulase negative and $36.13 \% \mathrm{~S}$. epidermidis, $38.7 \% \mathrm{~S}$. aureus, In addition, S. Epidermidis, S. Cohnii, S. Haemolyticus, S. Sciuri, S. Warner, S. hominis, S. Succinus, S. Carnosus, S. Caprae, S. Devriesei [14] were isolated. A regional Hawassa (Southern Ethiopia) with 160 milk samples were selected 78 isolates of $\mathrm{S}$. Aureus, which were resistant to vancomycin $-38.5 \%$, oxacillin - 60.3\%, ceftriaxone - 23.1\%, ampicillin - 70.9\%, Ammoxacillin-clavulanate - 30.9 [15]. Al-Bahry S. N., Mahmoud I. Y., Al-Musharafi S. K., and Sivakumar N. (Oman, 2014) with in their paper "Golden Staphylococcus. Infection during food production, preparation, processing and transportation ", reported that of 120 samples of nasal smears selected from workers who cook food, $66.2 \%$ were carriers of staphylococcus aureus. Samples of food products (meat products, eggs and egg products) were also selected, which in $28 \%$ of cases, S. aureus contained $39 \%$ of the samples; $92 \%$ of them were coagulasepositive, $15.5 \%$ were methicillin-resistant [16].

As regards the situation in the United States, there are reports of the spread of methicillin-resistant (MRSA) and methicillin-susceptible (MSSA) S. aureus in dairy tanks on Minnesota farms. So, of the 150 combined milk tanks samples from 50 farms collected during three seasons (spring, summer, autumn 2009), 93 MSSA and 2 MRSA isolates were detected. Also, the authors cite data on the detection of $0.6 \%$ of 846 MRSA isolates in Michigan, $1.8 \%$ of 2132 in Wisconsin. At the same time, in Vermont and Pennsylvania, the detection rate of MSSA was found to be $38 \%$ and $67 \%$ respectively [17].

The study, published in the American Society of Microbiologists (ASM) on applied and environmental microbiology in 2016, suggests that pathogenic microorganisms can also overcome the species barrier. The authors indicate that green monkeys in Gambia acquired Staphylococcus aureus from man: Staphylococcus aureus strains isolated from nose of healthy monkeys for biological properties were identical strains isolated from humans living in the area. [18]

In Europe, where the preferred types of intensive livestock is controlled not only livestock products subject to contamination by microorganisms of the genus Staphylococcus, and is overseeing the distribution of modified versions of staphylococci resistant to antibiotics. The European Food Safety Authority (EFSA) has released a 2015 report that provides data on the incidence of $S$. aureus (MRSA) in 
Europe. Methicillin-resistant staphylococci (MRSA) are staphylococci resistant to ß-lactam antibiotics. The mecA gene encodes the formation of a modified penicillin-binding protein and prevents the incorporation of $\beta$-lactam into the cell wall. Resistance of staphylococci to methicillin (oxacillin) represented known to us at present three main mechanisms: 1) Product penitsylinzv'yazuyuchoho additional protein (PZB) - PZB2a chromosomal gene encoded by mecA - a classic resistance to methicillin; 2) due to the inactivation of hyperproduction of ß-lactamase; 3) due to the modification of normal PSBs. MRSA, named at the site of the first isolation, with the profile of antibiotic resistance, are grouped in three molecular genetic groups of markers - the clonal complex (SS), the clonal lines (ST) and SPA type (t) [19]. Varieties of MRSA that cause human infection according to the European Food Safety Authority (EFSA) are divided into three main categories: the first is the hospital strains - healthcare associated (HA-) circulating in medical institutions, the second is strains circulating in Certain community groups - community-related (CA-), and the third group is the strains circulating among animals - livestock-associated (LA-) MRSA. HA-MRSA and CA-MRSA include strains that have a predominant effect on humans and are generally not related to productive animals. LA-MRSA has been found in pigs and poultry as well as other types of farm animals in many countries around the world. LA-MRSA can also be transmitted to a person, especially where there is a professional constant contact with the affected cattle and carcasses [19].

Significant fluctuations in the level of detection of MRSA between the countries of Europe can be noted. The analysis shows that in the countries of Northern Europe, the level of circulation of MRSA is much lower, compared with the countries of Southern and Southeastern Europe. Recent developments emphasize the usefulness of such monitoring, for example the detection of mecC-MRSA in pigs registered in Denmark [19]. MecC-MRSA was detected in domesticated pigs (a variety of animals that had not previously been reported) and the evidence presented indicates the transfer of mecC-MRSA between humans and pigs. In further development, the LA-MRSA (mec) strains were detected both in the urban population in Denmark and in poultry meat, which increases the probability of food-derived transmission of LA-MRSA [19] mec-MRSA found in approximately $2 \%$ of MRSA isolated from People in Denmark in 2010 and 2011 [19]. The mec-MRSA (mainly belonging to the spa t843) was found in pigs and farm workers in the same farm, which were closely interconnected, suggesting a transfer between humans and pigs on the farm. Genome sequencing and phylogenetic analysis showed the clustering of several isolates on the farm and isolated isolates from the farmer, which gave the authors the reason to consider the farmer as a source of staphylococci for animals [19]. Also, this report provides information that in 2015, Germany, Finland, Slovakia and Spain, as well as Switzerland provided information on the presence of MRSA in various categories of food products. In Finland, 303 portions of fresh meat of pigs were tested, of which $3,0 \%$ gave a positive result on MRSA. In Slovakia, MRSA was not allocated from food products. In Spain, fresh rabbit meat was investigated and five positive specimens were detected (8.3\%). In Switzerland, 301 pork samples were tested, $0.7 \%$ gave a positive result on MRSA. In Finland and Switzerland, the spa-typing was carried out for positive results. Spa type T034 (general SP-type related to CC398) was registered in Switzerland and Finland. In Finland, it has been established that spa type $\mathrm{t} 2741$ found in pig meat, also associated with CC398.

In 2015, Belgium, Germany and Spain, as well as Norway and Switzerland, provided data on the prevalence of MRSA among productive animals and the environment. In pigs, the prevalence of MRSA in animal slaughtering lots was estimated at a high level of $91.4 \%$ in Spain, while in Germany, the prevalence of MRSA in herds of sows (breeding areas) and herds of fattening pigs from the same establishments was detected in $26,3 \%$ and $41.3 \%$, respectively. In Switzerland, the prevalence of MRSA in pigs at slaughter was $25.7 \%$. In the herds of cattle in Belgium, the circulation of MRSA among cows and fattening animals was recorded at $10.4 \%$ and $15.4 \%$ respectively, and among the calves under the age of one year - $78.9 \%$ [19]

Data analysis for the Center for Disease Dynamics, Economics \& Policy (2015, USA) shows that in recent years (Fig. 1), the number of methicillin-resistant Staphylococcus aureus isolated from humans has a tendency to decline in Europe (France, Great Britain , Greece), the USA, the South African 
republic, unlike other countries of Central and South Africa, India, Australia and Latin America, which record a significant percentage of MRSA isolated from humans [20].

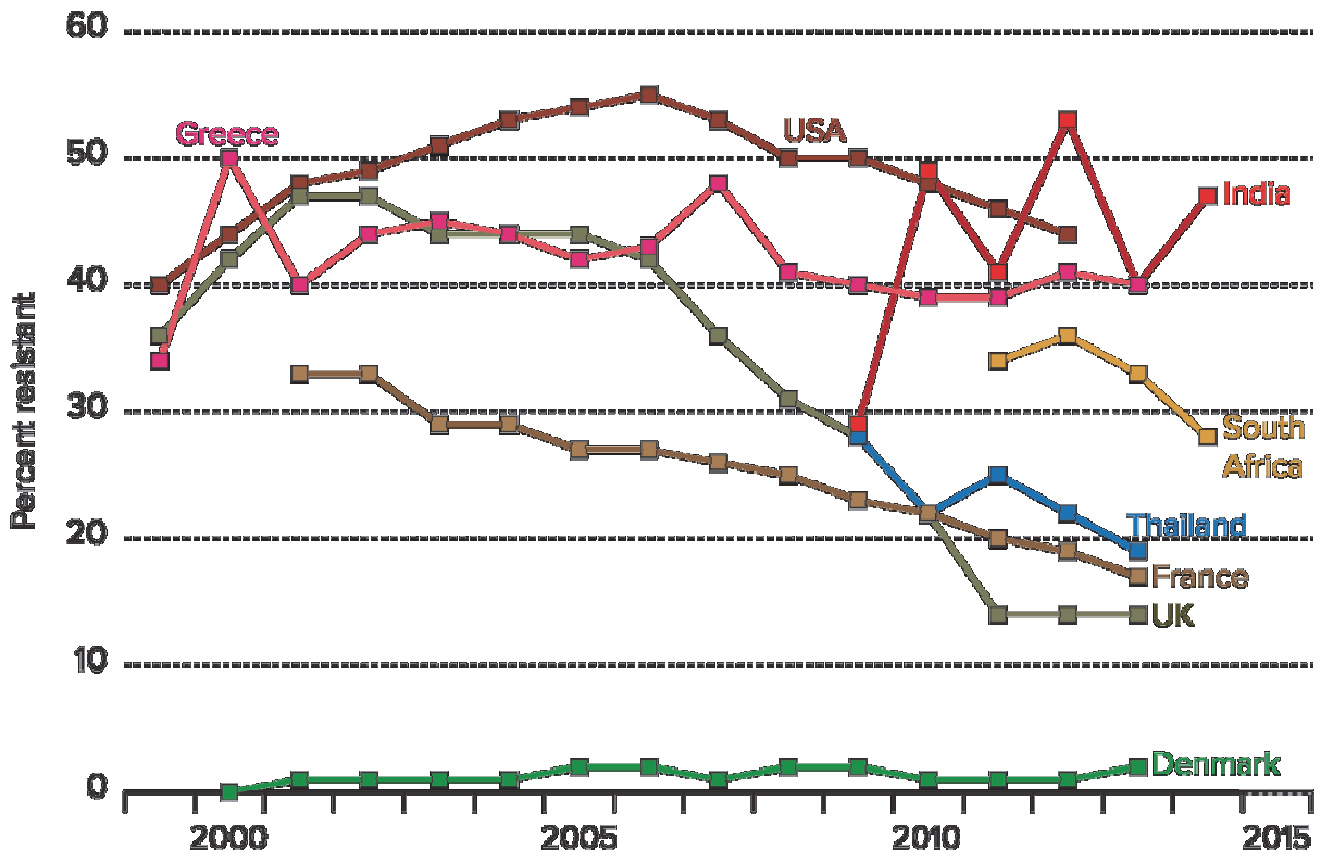

Fig. 1 The dynamics of MRSA detection in some countries, 1999-2014 (according to the CDDEP 2015

It should be noted that powerful pork production companies become stable MRSA internal reservoirs with zoonotic potential. In Norway, a study of 252 farms (EFSA, 2009b) and two national surveys conducted in 2011 and 2012 showed a very low prevalence of LA-MRSA in the pig population. The import of live pigs to Norway from other countries is negligible and this is an important factor in the epidemiological and biological protection of an industrial herd of pigs. Strategy elimination of LA-MRSA include annual screening populations of pigs, restrictions on trade in live animals suspicious disease, depopulation of pigs in LA-MRSA positive enterprises and thorough cleaning and disinfection of premises to the delivery of the pig population of MRSA-negative herds. After the stock is replaced, samples are taken from animals and from the environment to evaluate the effectiveness of eradication of MRSA. The analysis of the results of the implementation of the LA-MRSA liquidation procedure showed its high efficiency (in the first cycle $90 \%$ of the farms were healed. [19] This strategy of "finding and destroying" aims at preventing the spread of MRSA.

Over the last decade, LA-MRSA have spread to livestock in most European countries, prompting health authorities to implement the national monitoring program (Norway adopted a national strategy for monitoring and control of LA-MRSA in pig populations).

Our analysis of the official veterinary reports (site Derzhvetfitosluzhby) [21] showed that for the period from 1999 to 2013 was registered 22 unfavorable items on stafilokokozu - namely stafilokokozu poultry (1 point in 2004, by 2 points in 2005 and 2006, 1 point in 2007, 2010 and 2012); stafilokokozu pigs (1 point in 2001, 2005 and 2006, and 2 unfavorable points in 2007), stafilokokozu dogs (one - in 2004, two - in 2005 - one in 2006 and 4th 2013); Staphylocococytosis of cats (1 point in 2013). These data indicate the feasibility of improving surveillance systems for diseases caused by staphylococcus, circulation pathogen populations of susceptible animals and food contamination by staphylococci.

According to [22] in 2014 Ukraine was registered three cases of MRSA isolation from cows suffering from mastitis in Dnipropetrovsk and Donetsk regions, according to the statements of the Ivano-Frankivsk Regional State Laboratory of Veterinary Medicine also found MRSA from fur animals. The increase in the frequency of MRSA secretion in people who, by the nature of their professional activity, are in contact with pigs and pigs may indicate the transfer of the pathogen between animals, slaughter products and humans. 
According to Pokrychko O.V., Klymniuk SI (2017), in the examination of 243 persons, the phenomenon of the transmission of $\mathrm{S}$. aureus was detected in $15.0 \%$ of high school students, $23.3 \%$ of medical students and $33.9 \%$ of medical staff. In workers of the surgical hospital high level of mucosal insemination was detected in $61.1 \%$ of the surveyed. The authors emphasize that the highest number of antibiotic resistant strains of staphylococcus aureus was found among the medical staff of the surgical department. The established high resistance of isolated strains to oxacillin allows to characterize them as epidemicly dangerous [23].

It should be recalled that Ukraine does not have a program to monitor the prevalence of staphylococci in animals and humans, and there is no observation of their biological properties (antibacterial resistance, microbial contamination). No programs have been developed for the elimination of outbreaks among animals and the rehabilitation of carriers.

Directions of further research.The purpose of further research is to analyze the epizootiological and epidemiological situation regarding staphylococcal infection in Ukraine. Investigation of the biological properties of staphylococci isolated from various biological objects, food and the environment. It is planned to monitor the prevalence of the phenomenon of antibiotic resistance in these microorganisms and to study the spread of the pathogen and its variability in order to prevent the disease of animals and humans.

\section{Conclusions.}

1. Staphylococci are extremely common microorganisms. Staphylococci is susceptible to all types of pets and pizza as well as humans. Patients are very often a carrier and a source of illness for other people and animals, and the severity of the disease depends largely on the state of the macro-organism;

2. Food products of animal origin due to improper process of their manufacture, transportation, storage, preparation and consumption may be a source of a pathogen of staphylococci; 3 . The development of microbial microbial resistance to antimicrobial drugs is rapid and complicates the treatment process and leads to significant economic losses. 4. To prevent outbreaks of food infections, the source of which is the bacteria of the genus Staphylococcus, it is necessary to create modern schemes for the monitoring of food products during their manufacture and storage, to introduce a national control system for staphylococcus as a pathogen for food infections.

\section{Bibliography}

1. Dzh. Khoulta, Kriga N., Snita P., Steyli Dzh., Uill'yamsa S. (Ed.). (1997). Kratkiy opredelitel' bakteriy Bergi. V 2-kh t. T 2: Per. s ang. Moskva: Mir, 1997. $368 \mathrm{s.}$

2. Volobuieva L.M., Rusalov V.L., Salmanova O.M. (2013). Vydovyi sklad ta biolohichni vlastyvosti stafilokokiv endohenoho pokhodzhennia, shcho ye zbudnykamy piodermii. Ukrainskyi medychnyi almanakh. tom 16, № 2. S $16-18$.

3. María Ángeles Argudín, María Carmen Mendoza, María Rosario Rodicio (2010). Food Poisoning and Staphylococcus aureus Enterotoxins. Toxins (Basel). Vol. 2, iss. 7. P. 1751-1773.

4. Verbytskyi P.I., Dostoievskoho P.P. (Ed.). (2004). Dovidnyk likaria veterynarnoi medytsyny. Kyiv: Urozhai. 1278 s., S. 257.

5. Pedan V.A. (2004). Bakterii rodu Staphylococcus - zbudnyky stafilokokozu perepeliv. Visnyk Sumskoho NAU. Vyp. 2(11). Sumy. S. 112-114.

6. Hamiroune M, Berber.A, Boubekeu. S. (2014). Contribution to the study of staphylococcus contamination of cows' milk on a number of farms in Algiers: its impact on human health. Rev. sci. tech. Off. int. Epiz. 33 (3). P. 1035-1041.

7. Donkor E.S., Aning K.G., and Quaye J. (2007). Bacterial Contaminations of Informally Marketed Raw Milk in Ghana. Gana Medical Journal. Jun; 41(2). P. 58-61.

8. Microbial Evaluation of Raw Milk from Dairy Farms in Udi L.G.A Enugu State, Nigeria, Nwankwo, Immaculata, Amaechi, Ndubuezeand, Adiele, Winnie. IOSR Journal of Agriculture and Veterinary Science (IOSR-JAVS) Volume 8, Issue 3 Ver. III (Mar. 2015). PP 60-65. 
9. Sileshi Shiferaw and Munees Ahmad. (2016). Prevalence and antibiotic susceptibility of Staphylococcus aureus from lactating cow's milk in Bahir Dar dairy farms. African Journal of Microbiology Research. Vol. 10(35), pp. 1444-1454.

10. Enquebaher Tarekgne, Siv Skeie, Knut Rudi, Taran Skjerdal and Judith A. Narvhus. (2015). Staphylococcus aureus and other Staphylococcus species in milk and milk products from Tigray region, Northern Ethiopia. African Journal of Food Science. Vol. 9(12) pp. 567-576.

11. Deresse Daka, Solomon G., Silassie and Dawit Yihdego Daka et al. (2012). Antibioticresistance Staphylococcus aureus isolated from cow's milk in the Hawassa area, South Ethiopia. Annals of Clinical Microbiology and Antimicrobials. №9.

12. Haran K.P., Godden S.M., Boxrud D., Jawahir S., Bender J. B. and Sreevatsan S. (2012). Prevalence and Characterization of Staphylococcus aureus, Including MethicillinResistant Staphylococcus aureus, Isolated from Bulk Tank Milk from Minnesota Dairy Farms. J. Clin. Microbiol. March. Vol. 50 № 3. P. 688-695.

13. Green Monkeys Acquired Staphylococcus Aureus From Humans. Applied and Environmental Microbiology. Washington, DC. July 29, 2016. 2 p.

14. The European Union summary report on antimicrobial resistance in zoonotic and indicator bacteria from humans, animals and food in 2015. EFSA Journal. Vol. 15, Issue 2, February 2017. 212 p.

15. The state of the world's antibiotics. Center for Disease Dynamics, Economics \& Policy. 2015. State of the World's Antibiotics, 2015. CDDEP: Washington, D.C. 84 p.

16. Harkavenko T.O., Kozytska T.H., Ordynska D.O. et al. (2015). Metytsylinrezystentnyi stafilokok (MRSA) - stan problemy u sviti ta v Ukraini. Beterynarna Biotekhnolohiia. №26. P.41-51.

17. Pokryshko O.V., Klymniuk S.I. (2017). Nosiistvo zolotystykh stafilokokiv sered riznykh hrup naselennia. Materialy vseukrainskoi naukovo-praktychnoi konferentsii z mizhnarodnoiu uchastiu «Infektsiinyi kontrol ta antymikrobna rezystentnist u haluzi hromadskoho zdorovia i veterynarii». S.70-71. Kyiv, Ukraina. 